Rosen, Ilana. "Fragments of a Hungarian Past in the Literature of 1.5 and Second-Generation Austro-Hungarian Immigrants in Israel." Hungarian Cultural Studies. e-Journal of the American Hungarian Educators Association, Volume 7 (2014): http://ahea.pitt.edu DOI: 10.5195/ahea.2014.138

\title{
Fragments of a Hungarian Past in the Literature of 1.5 and Second- Generation Austro-Hungarian Immigrants in Israel
}

\section{Ilana Rosen}

\begin{abstract}
Contemporary Israeli literature is presently preoccupied with the past diasporic lives of the previous generation, the one that came to Israel from practically all four winds in the mid-late twentieth century. Hungarian-Israeli writers-e.g., Yoel Hoffmann, Judith Rotem, Yael Neeman and Esti G. Hayim - constitute a distinct group within this stream of 1.5 and second generation poets and novelists who have written about immigration and State foundation, often using a documentary or fictionalized memoirist mode. This article highlights the components of these writers' complex burden of a whole world destroyed, in most cases, not long before they were born and which they strive to restore or at least reimagine in their oeuvre as contemporary Israeli writers. These components include: Holocaust trauma and its transference to the second generation, Hungarian speaking families within the Israeli multicultural setting, the ties of these families with their Hungarian foreign relatives, and household objects related to this past. In most cases, the attempt to revive or retrace the Hungarian past of these families proves to be an impossible mission and the narrator children are forced to reach the realization that they are, probably, a "desert generation"; that is, the last to even recall and reverberate the lost, bygone worlds of their Hungarian-Jewish parents.
\end{abstract}

Keywords: Israeli Literature, Hungarian Israelis, Holocaust Narrative, Immigration, Second Generation, Postmemory, Judith Rotem, Yael Neeman, Esti G. Hayim

Biography: Ilana Rosen studies the documentary literature of Jews of Central Europe as well as the multi-ethnic narrative of emigration to and foundation of the south of Israel. Her publications include: Sister in Sorrow: Life Histories of Female Holocaust Survivors from Hungary (Detroit, MI: Wayne State UP, 2008); Soul of Saul: The Life, Narrative, and Proverbs of a Transylvanian-Israeli Grandfather (Burlington, VT: Vermont University, 2011).

In recent decades, the Israeli scene of literary, artistic, and cultural creation has been laden with the memory of the bygone worlds of the contemporary generation of approximately middle-aged people who have reached prominent positions in Israeli intellectual, cultural, and artistic circles. An illustrative example of this phenomenon is the work of people of Oriental or (in Hebrew) mizrahi origin, which is greatly inspired by African and Indian postcolonial doctrines in its wish to sound the voice of the hitherto unheard "subaltern" (see, for example, Shenhav 2006, The Arab-Jews). Another phenomenon that is just as present as the work of mizrahi authors yet not that strongly trumpeted in political terms is the literary work of children of Holocaust-survivor parents from Europe depicting the early period of their families in the 
Rosen, Ilana. "Fragments of a Hungarian Past in the Literature of 1.5 and Second-Generation Austro-Hungarian Immigrants in Israel." Hungarian Cultural Studies. e-Journal of the American Hungarian Educators Association, Volume 7 (2014): http://ahea.pitt.edu DOI: 10.5195/ahea.2014.138

young, centralist, and socialist State of Israel of the 1950s and 1960s. Interestingly, quite a few of these writers have Austro-Hungarian roots, as their parents were-and sometimes they, too, are-Hungarian- or Romanian- or Slovakian- or Carpatho-Rusyn-born. A more inclusive survey of Austro-Hungarian Israeli writers, poets, journalists, translators, and caricaturists/artists is necessarily generational and includes the following personae and grouping (the appendix below offers fuller details about each writer; see also Galron-Goldschläger's on-line and Stavi and Schwartz's 2014 printed Modern Hebrew Literature Lexicons).

The forefathers or forerunners of Austro-Hungarian Israeli writers and poets are Avigdor Hameiri (Foyerstein) (1890-1970), Mordechai Avi-Shaul (Mandel) (1898-1988), and David Giladi (Klein) (1908-2009), all three of whom were born in the Austro-Hungarian Monarchy and emigrated as adults to British-Mandate ruled Israel/Palestine (I/P) in the 1920s and 1930s. The first generation of Austro-Hungarian Israeli writers and poets includes Hanna-Anna (Anikó) Szenes (1921-1944), Ephraim Kishon (Ferenc Kishont-Hoffmann) (1924-2005), and caricaturists/artists Shraga Weil (1918-2009), Shmuel Katz (1926-2010), Ze'ev (Heb.: 'wolf,' née Yaakov Farkash, 1923-2002), and Dosh (pen name of Kariel Gardosh, née Goldberger, 1921-2000). All of these authors and artists, except for Szenes, who had a famous history of her own as a kibbutz pioneer and later as a secret agent to Nazi-ruled Hungary, where she was caught and executed (Glick 2013), went through World War II and the Holocaust, either as forced laborers in the Hungarian army or in other work or camp settings before arriving in I/P, or to the State of Israel as of 1948 (Rosen 2012). Both the forefathers-forerunners and the first generation writers are relatively widely known to this day, at least partly because they were also active in pre-State and early Israeli journalism of all sorts. Note also that most of them are highly educated men.

"The 1.5 generation" — an identity term coined by Susan Rubin Suleiman (see her 2002 American Imago article) that refers to those in between the first and second generationsincludes writer Shulamit Lapid (b. 1934, Tel Aviv), David Giladi's daughter, poet Itamar YaozKeszt (b. 1934, Szarvas), Asher Reich (b. 1937, Jerusalem), and Yoel Hoffmann (b. 1937, Brasov, Romania), the internationally most renowned of all past and present Israeli writers of Hungarian origin. Also included in this "half-generation" are the somewhat less well-known poets Moshe Ganan (János Kertész) (b. 1931, Budapest), Yaakov Barzilai (b. 1933, Debrecen) and Eli Netzer (Schnitzer) (b. 1933, Budapest), who in 1991 founded Ma'arechet ['Editorial'] Press at Kibbutz Dalia, which published many Holocaust and immigration memoirs by former Central European people. Prolific novelist Judith Rotem (b. 1942, Budapest) is likewise a 1.5 generation writer, whose work I will discuss in more detail in this article. Excluding Shulamit Lapid and Asher Reich, this entire half generation, like the first, lived through the Holocaust in Hungary, only they were young children up to teenagers before leaving for I/P; some of them, like Yoel Hoffmann and Judith Rotem, probably have no independent memories of their Hungarian lives, while the older ones among them surely remember more.

The second generation of Austro-Hungarian Israeli writers and poets includes mostly Israeli-born descendants of Austro-Hungarian immigrants, most of whom were Holocaust survivors, with a conspicuous component among them of leftist-socialist kibbutz people. While still in their original home countries, the parents may have been observant-religious (Orthodox), if not assimilated Jews, and, in many cases, upper to lower middle class. Considering their life history, it may well be that these people joined the kibbutz frame in search of a sense of family, community, and meaning in order to compensate for their suffering and losses in the Holocaust, and/or to contrast their pre-war religious or bourgeois life. Fewer still of this (parents) generation 
Rosen, Ilana. "Fragments of a Hungarian Past in the Literature of 1.5 and Second-Generation Austro-Hungarian Immigrants in Israel." Hungarian Cultural Studies. e-Journal of the American Hungarian Educators Association, Volume 7 (2014): http://ahea.pitt.edu DOI: 10.5195/ahea.2014.138

joined Zionist-socialist youth movements already in Hungary or Romania or Carpatho-Rus'. Unlike the first generation of mostly male Austro-Hungarian Israeli writers and poets, the second generation is almost exclusively female. This generation includes poets Agi Mishol (b. 1946, Szilágycheh/Chehu silvaniei, Romania), Hezi (Ezekiel) Leskli (1952-1944, Rehovot, Israel), Miriam Neiger Fleischmann (b. 1948, Komárom/Komarno, Czechoslovakia), Dorit Weissman (b. 1950, Kfar-Sava, Israel) and the less well-known Robi Schoenberger (b. 1960,

Temesvár/Timisoara, Romania); journalist Carmit Guy (b. 1949, Kibbutz Givat Hayim), novelist and young-readers writer Rivka Keren (Katalin Friedländer) (b. 1946, Debrecen), poet and novelist Ofra Offer (b. 1951, Tel Aviv), novelists Suzanne Adam (b. 1952, Szatmár/Satu Mare, Romania) and Shoshi Brainer (b. 1952, Haifa); and the more recent short fiction and novel writers Yael Neeman (b. 1960, Kibbutz Yehiam) and Esti G. Hayim (b. 1963, Jaffa), both of whom have in the last few years published compelling books that I discuss below. Modern Hebrew literature researcher and editor Yigal Schwartz (b. 1954, Ramat Gan) has recently joined this group/cohort with a tantalizing literary memoir. The group of second generation HungarianIsraeli writers listed here cannot be finite, as some of its members have only recently started to address their Hungarian and Holocaust legacies in their writing, so possibly others, too, may still join them.

The third generation to date of Austro-Hungarian Israeli writers and poets includes only one member, the writer, translator, and musician Dávid Tarbay (b. 1977, Budapest), son of writer Ede Tarbay and researcher Anna Szalai, with whom Dávid emigrated from Hungary at age fourteen. Because of his non-Israeli childhood and growth, Tarbay actually belongs to a different category than the second generation of Austro-Hungarian Israeli writers and poets listed above, especially the Israeli-born among them, and he would rather belong with those of the 1.5 generation who came to Israel as adolescents, with the difference that they lived through the Holocaust, and he grew up under communism. Otherwise, the very label "Third Generation Israeli Austro-Hungarian Writers" is almost a contradiction in terms, as in most cases these writers, if at all aware of their family roots, are too remote or estranged or ignorant to deal with them in depth.

To date very little research has been published about the Hungarian identity aspects of the entire group of Austro-Hungarian Israeli writers and poets and their work, and most of it exists mainly or only in Hebrew. ${ }^{1}$ Moreover, to this day in Israel as well as in non-Israeli Hebrew literature scholarship they are erroneously related to as Eastern- rather than Central-European or Austro-Hungarian, which distorts the conception of their past worlds as depicted in at least some of their work. It should be noted that although Israeli society is practically multicultural, nevertheless social and literary-cultural researchers often tend to describe it as made up of polar blocks by geographical and cultural origin (European ashkenazim vs. Middle Eastern mizrahim), or by level or religiosity, like secular vs. religious, which falls far short of accounting for the inner variation within each large group. An innovative contribution in this sense is Yigal

\footnotetext{
${ }^{1}$ These studies include: Schwartz (2014), Ruti Glick's monograph on Hanna Szenes/Senesh (2013), my interwar and Holocaust narrative studies (Rosen 2003, 2004, 2011), a relatively rich scholarship on Yoel Hoffmann, and parts of works devoted to Hebrew literature historiography (Shaked 2000), Holocaust memory and narrative, ultra Orthodox narrative, kibbutz lore, humor, and Israeli journalism.
} 
Rosen, Ilana. "Fragments of a Hungarian Past in the Literature of 1.5 and Second-Generation Austro-Hungarian Immigrants in Israel." Hungarian Cultural Studies. e-Journal of the American Hungarian Educators Association, Volume 7 (2014): http://ahea.pitt.edu DOI: 10.5195/ahea.2014.138

Schwartz's new study, Ashkenazim - hamerkaz neged hamizrah ['Ashkenazim: Center vs. East'] (2014), which redefines the unique figure, poetics, and thematic coverage of Israeli writers of Central-European and Austro-Hungarian origin, although Schwartz himself also includes Aharon Appelfeld (born in 1932 in Zhadova/Jadova, Bucovina) among the Austro-Hungarian writers, which for linguistic, thematic, and cultural reasons I would not.

Based on the foregoing generational survey of Austro-Hungarian Israeli writers and poets, I will now deal more closely with the presently active 1.5 and second generation writers and with their central fictional prose works that bear evident biographic components. I will primarily discuss works by Judith Rotem, Yael Neeman, and Esti G. Hayim, and will also discuss more briefly Ora Ahimeir's Kalla ['Bride'] (2012), written by a writer who is herself of non-Hungarian origin, about the first, four day-old marriage of her mother to a man from Sátoralyaujhely in Northeastern Hungary, where she retraces this short-lived relationship in which, tragically, the young bridegroom was killed in Safed in northern I/P in the 1938 Arab Revolt events (Swedenberg 2003). In all of these 1.5 and second generation works relating to the Hungarian roots of the writers, there are conspicuous thematic, rhetorical or stylistic, psychological and cultural traits that together make up the shared portrait of these works and their authors as the Hungarian substream within the contemporary Israeli stream of second generation to the Holocaust, fin du colonialisme, immigration, and State foundation writers and writing. Here I offer an outline of a few of the most salient and recurrent characteristics or "symptoms" of Hungarian-Israeli writers and their writing, hoping to further develop their discussion and analytic treatment in future works.

The work of the 1.5 and second generation Austro-Hungarian Israeli writers, somewhat like that of their Polish-Israeli counterparts, for example, Alona Frenkel, Aliza Olmert, Zipora Rozensher-Dolan and Relli Robinson, is heavily burdened with the memory of the Holocaust. To quote Dvori Stern, Esti Hayim's child protagonist in Anshei pinot ['Corner People'] (2013), who, like the author, grew up in Haifa of the 1960s and 1970s:

She [the mother of Dvori's friend Ayala] was not ok, and neither were the moms of the queen of our class, Na'ama, and of her deputy, Anat, nor Eli's mom... [We lived, mentally, in] Auschwitz corner of Birkenau... These kids kept in secret that their moms were nuts, and I always thought that only mine was $(213$, my translation from the Hebrew original).

As shown in many psychological and literary studies on the second generation of the Holocaust (Vardi 1992; Hass 1996; Bar-On 2000; Milner 2007), as present as the memory of camps and other horrific settings was around these children of survivors, at the same time it was also cloistered, encoded, and beyond their reach. ${ }^{2}$ Often, as depicted in several works by Yael Neeman, Esti Hayim, and Yigal Schwartz, the Holocaust-related traumas of the parents are expressed through their inadequacy and neglect toward their children; and, as in the work of

\footnotetext{
${ }^{2}$ The tension between the felt presence of the Holocaust trauma and the attempts to conceal or ward it off in Israeli survivor families is forcefully depicted by David Grossman (himself a non-second-generation to the Holocaust and non-Hungarian writer) in his See Under Love (2002, Heb. 1986).
} 
Rosen, Ilana. "Fragments of a Hungarian Past in the Literature of 1.5 and Second-Generation Austro-Hungarian Immigrants in Israel." Hungarian Cultural Studies. e-Journal of the American Hungarian Educators Association, Volume 7 (2014): http://ahea.pitt.edu DOI: 10.5195/ahea.2014.138

Neeman and Hayim, it is primarily the mothers who pass on their mental hardships to the narrator daughters, who portray themselves as at least partly deranged young women as a result of such a family upbringing. In the novels of these three second-generation writers the fathers, by contrast, though definitely carrying their own Holocaust related burdens, seem to exist outside this loop either because they are mostly away, working (in the kibbutz lifestyle of the time, families met only in the afternoon hours, and children slept and lived all year long in age-group "children-houses"), or because they have or feign a more robust mental setup, or because they have alternative relationships with other women. One way or another, the parent that is portrayed as more vulnerable, verbal and present in the children's lives is the mother, including in the kibbutz frame where allegedly she works and spends as much time away from her children as their father. Somewhat differently, in Schwartz's memoir the mother neglects her children, often deserting the home for months following bitter quarrels with her husband.

A central thematic and rhetorical component in the works of the 1.5 and second generation Austro-Hungarian Israeli writers is the peculiarities of the parents' difficulties in mastering Hebrew, as shown or "heard" throughout their distinct and often ridiculed intonation and mispronunciations (Rosenhouse 2012). The issue of foreign accents and languages appears, unsurprisingly, very often in Israeli literature of all geographic and linguistic backgrounds telling about the pre-Holocaust or pre-Jewish-State life of Jews abroad in Hungary, Poland, Morocco, or Libya; in the last decade and a half this literature may integrate from single foreign words to entire sentences, sometimes without translation to Hebrew. In most cases, the writers use only Hebrew transcription for these texts and much of the foreign language text (in whichever transcription) is faulty or sub-standard, probably because of the writers' wish to present the foreign language the way they heard it and - it has to be spelled out - their negligence or ignorance of the foreign language spoken by their previous generations. In addition, except for Yiddish and Judeo-Spanish (or Ladino), there is no standardized Hebrew transcription of foreign languages, although there are some conventions deriving from older traditional or scholarly works, so one might expect a whole range of idiosyncrasies in these foreign language representations in Hebrew literature.

For example, in Hayinu he-atid ['We Were the Future'] (2011), Neeman describes a short exchange that her kibbutznik parents have over the heads of their children about the old world and the Holocaust. Suddenly, her father breaks up the conversation by roaring the single Hungarian word 'haggyad' ['let go of it' or 'cut it off']. For Neeman, this is a word that is not one, but two: hagy and ad, or hagy and gyad (which Neeman spells had-jad), because, presumably, this was the emphatic way the father pronounced this word in his anger or anxiety and the narrator daughter heard and conceived of it as a term relating to her parents' old world. In the context of the idealistic kibbutz world, in which the bourgeois, decadent, diasporic, and traumatic past and its language(s) were banned and silenced, this one foreign word is singular in Neeman's otherwise all-Hebrew, vital depiction of her kibbutz cohort of the 1960s and the 1970s. Nevertheless, one might wonder why she could not be more careful about the accurate presentation of this single and significant word in her forceful work as an Israeli writer decades later.

Unlike Neeman, who foregrounds only a single word of Hungarian in her text, Hayim in her recent Anshei pinot ['Corner People'] integrates entire Hungarian exchanges she heard and took part in, but nevertheless she, too, imposes her personal-familial aural scale on the conventional norm. A conspicuous example of Hayim's use is the Hungarian vowel |a|, which does not exist in Hebrew, that only has |á| and |o|, and which Hayim systematically presents as 
Rosen, Ilana. "Fragments of a Hungarian Past in the Literature of 1.5 and Second-Generation Austro-Hungarian Immigrants in Israel." Hungarian Cultural Studies. e-Journal of the American Hungarian Educators Association, Volume 7 (2014): http://ahea.pitt.edu DOI: 10.5195/ahea.2014.138

$|\mathrm{o}|$. Hebrew does have two conventions for the spelling of |á|, marked with two different subletter punctuations called patah and kamats; and of these two, kamats has a variation called "small [kamats katan]" that is used to represent the Hungarian vowel |a|, which in Hungarian is an entirely different phoneme. Now, Hayim's dismissal of this convention makes her Budapest family sound like people from more remote parts of the old country, with words like 'ablak' ['window'] sounding like $\mid$ oblok $\mid$ and 'fasirt' [a hamburger-like patty] sounding like |fosirt|. Hayim also has slight mistakes like 'Olaszorszák' for Olaszország ['Italy'], and like inserting 'szija' ['hello' or 'Goodbye'] into the interwar Hungarian parlance of her previous generations, though according to Gábor Zaicz's Etimológiai szótár ['Etymological Dictionary'] (2006: 950), this usage did not exist until the 1970s.

Compared to Neeman and Hayim, Judith Rotem's phonetic misrepresentations are more moderate, probably because she grew up in a Hungarian (and sometimes Hungarianized Yiddish) speaking observant-religious Israeli family, albeit she, too, does not control the nuances of the written Hungarian language. Interestingly, while Hungarian-Israeli authors such as Neeman and Hayim commit these orthographic errors, other writers not at all of Hungarian background do not. For example, the Egyptian-born Israeli author Rabbi Hayim Sabato, in his From the Four Winds (2010), represents the Hungarian speech of his Jerusalemite Hungarian-born, Holocaust survivor immigrant neighbors of the 1950s and 1960s in complete keeping with publicist and academic conventions, probably aided by professional translation and editing, and the same is true for Ora Ahimeir in Kalla ['Bride'] (2012).

Hungarian as a language, with its intonation and influence on the Hebrew speech of its users, used to have the role of serving as embarrassing laughing stock of the second generation sabra [Heb. and Arabic: 'Pricky Pine'; Hebrew slang for Israeli-born] children and their environment of the 1950s and 1960s; but it is to this day also seen or heard among its Israeli speakers as a language of warmth and endearment, helping to conjure about favorite dishes and - more generally - the parents' forever lost and gone previous worlds. Some of these "children," like Judith Rotem and Esti Hayim, grew up speaking or at least hearing and responding to the simple, everyday Hungarian spoken by their parents, who spoke very poor Hebrew; while others, like Neeman, who grew up in the strict Kibbutz Yehiam society, barely understood it.

In the novels of Judith Rotem and Esti Hayim, language issues are sometimes connected to the figures of non-Israeli relatives of these Holocaust-survivor dwindled immigrant families, because the relatives are the ones with whom the funny-sounding language is made necessary and even respectable. In two novels, Ahavti kolkakh ['I Loved So Much'] (2000) by Rotem and Anshei pinot ['Corner People'] by Hayim, these relatives are lone, foreign aunts whose presence in the novels is flickering, as they come and leave (in Rotem's novel Aunt Gabriella, originally from Budapest, tried to live in Israel in the mid twentieth century but eventually emigrated with her third husband to West-Germany; in Hayim's novel Aunt Esti suddenly lands from Budapest in the late 1960s and joins her Israeli family, apparently leaving her child in Hungary, and nothing is said about any spouse), and controversial, because their Israeli siblings criticize and bear decade-old grudges against them. In spite of the fact that their presence often means family arguments, the Israeli children adore their foreign aunts because they give them the attention and understanding that their busy or strict or dysfunctional parents do not. In both Rotem's Ahavti kolkakh and Hayim's Anshei pinot, the non-Israeli Hungarian-Jewish aunts are exceptionally good looking - to the point of making their Israeli relatives gossip or mutter that they may have (mis-)used their femininity in the hard times - and somewhat deranged a-là Blanche Dubois 
Rosen, Ilana. "Fragments of a Hungarian Past in the Literature of 1.5 and Second-Generation Austro-Hungarian Immigrants in Israel." Hungarian Cultural Studies. e-Journal of the American Hungarian Educators Association, Volume 7 (2014): http://ahea.pitt.edu DOI: 10.5195/ahea.2014.138

(referring to American playwright Tennessee Williams' protagonist in Streetcar Named Desire, 1995 [1947]); yet, in their own way, these strange aunts are resilient survivors. Thus these foreign aunt figures are also thematized as a non-Israeli, non-familial option contrasting the Israeli option of seemingly normal but evidently tense, complicated, and miserable families and relationships.

An interesting comparison with Israeli writers who write about the Hungarian-Israeli extended family is Hungarian writers writing about the fate of Hungarian Jewish families who remained in Hungary after the war, as surveyed by Rita Horváth, wherein the shrunken survivor family is depicted in mythical terms that extend to its alleged ancestral past of decades or centuries prior to Destruction (Horváth 2004). Thus, in the case of the Hungarian-Jewish survivor family novel, the loss and lack of real flesh and blood relatives is compensated for in temporal terms, as these novels may go back to the family's eighteenth-century or medieval generations, whereas in its Israeli counterpart the loss and lack of present relatives are filled in by spatial terms and with remote relatives that also act as part-time parent surrogates to the narrator children.

Some 1.5 and second generation Hungarian-Israeli authors often include elaborate allusions to lifestyle or habitat issues like detailed descriptions of foods, kitchenware, clothing, cosmetics, furniture, décor, and religious objects, whose significance for the Hungarian-Jewish family, including the Israeli children, goes way beyond their financial, functional or merely sentimental value. A forceful and lengthy example for this sensuous-tangible memory voyage occurs in Ora Ahimeir's Kalla ['Bride'] (2012), where a large part of this novelized memoir is devoted to the widowed bride's journey - following a four day-old marriage - to her would-be, warm and loving Ujhely family in the uncertainty of early 1939. She travels there with her father to take part in the Jewish ceremony of halitzah, releasing her of yibum ['levirate marriage'], meaning the dictate that the younger brother (a bachelor) of the deceased must marry the widow to symbolically continue the seed of his dead brother (Deuteronomy 25, 5). Apart from going through the solemn ceremony, the widowed bride also meets her short-term Ujhely relatives, their home, vineyard, the Kálmán Klein fancy textile shop and sewing salon where her two would-be sister-in-laws work, and a whole physical and tactile world of sensations, with which she has to part forever at the end of her sad journey, and which, as the author later learns, was almost entirely annihilated soon afterward (169-194).

No doubt, though, Judit Rotem is the most exemplary or salient of all Austro-Hungarian Israeli writers in her tendency toward the integration of the habitat of the bygone HungarianJewish or Hungarian-Israeli home. In the following excerpt from her Matay tavo elay ['When Will You Come to Me'] (2012), Protagonist Shulamit, an observant-religious middle-aged woman on the verge of divorce, is reminded of her early motherhood experiences:

After she had her first baby, a daughter, Shulamit came to rest at her parents' home. Her mother would bake her dry butter cookies to make her thirsty, so she would drink a lot and have enough milk to breastfeed the baby. With a surge of renewed motherly enthusiasm, she'd make her Hungarian specialties: rich broths, lecsó ['pepper and tomato stew'] with chopped eggplant and scrambled eggs shining with oil, or a kohlrabi and potato fözelék ['dish'], chicken goulash with paprikás potatoes, and fried chicken livers with onion rings. "It's Aranka [her mother's childhood home cook/housekeeper] who taught me all this" (100, my translation from the Hebrew original). 
Rosen, Ilana. "Fragments of a Hungarian Past in the Literature of 1.5 and Second-Generation Austro-Hungarian Immigrants in Israel." Hungarian Cultural Studies. e-Journal of the American Hungarian Educators Association, Volume 7 (2014): http://ahea.pitt.edu DOI: 10.5195/ahea.2014.138

These objects and their past and present locations and potential for evoking a variety of senses and memories all tell the story of a group that thrives on refinement, moderateness, and avoidance of extremes, whereas in the case of families of even more humble Hungarian homes (as in Neeman's, Hayim's, and Schwartz's books), these objects lack the aura of refinement, though they still stand for "there" and are seen as relics by the immigrant family's Israeli children.

Due to their sensitivity to objects, spaces and passages back and forth between "there" (mid twentieth-century Austro-Hungarian locales) and "here" (Israel of the 1950s and the 1960s), writers like Judith Rotem, Yael Neeman, Esti Hayim and Ora Ahimeir can be seen as eye as opposed to ear and tongue writers, to quote Yigal Schwartz's differentiation in his recent study Ashkenazim (Schwartz bases himself on Dmitry Merezhkovsky's essay in Mir iskosstva of 1901 concerning the styles and sensibilities of the two Russian master writers Leo Tolstoy and Fyodor Dostoevsky; see Schwartz 2014: 13-15). In the context of the present Hungarian-Israeli 1.5 and second generation writers, space - even in its micro level of house or shop interiors and kitchen objects - could be added to eye to reach a more balanced negation with the ear and tongue pole of literary sensibility and expression, which according to Schwartz's study stands for EastEuropean Jewish and Israeli writers and writing.

To conclude, the 1.5 and second generation Israeli writers of Austro-Hungarian origin whose writings I have sketchily outlined is a small but significant group within a larger cohort of Israeli writers of various countries of origin writing about the lives of their immigrant families in the first decades of the young State of Israel. Here I focused on the biographically determined prose fiction written by these Hungarian-Israeli writers and highlighted the components of their complex burden of a whole world destroyed, in most cases, not long before they were born and which they strive to restore or at least re-imagine in their oeuvre as contemporary Israeli writers. These thematic or linguistic components were: Holocaust trauma and its transference to the second generation by the heavily traumatized parents, language peculiarities within a nationfoundation setting, ties with Hungarian or central European foreign relatives, and the fetishization of everyday family objects as relics of those lost lives.

In most novels or novelized memoirs surveyed in this article, the attempts at reconstruction of, or reconciliation with, the Hungarian-Jewish past are crowned with only very partial success, leaving this past forever lost and blurred, forever beyond reach, so that all that remains for these 1.5 and second generations of Hungarian-Israeli writers is pidgin Hung-brew and scraps of recipes of favorite foods, or perhaps only their remembered flavors. These writers are probably the last ones to have lived in close contact with the past Hungarian world of their parents and forefathers, as becomes evident by the lack of an Israeli-born third generation of Hungarian-Israeli writers. We might, therefore, view these writers as a last "desert generation" (as their parents were labeled in Israel's first years, somewhat like the ancient Israelites on the verge of entering Eretz Israel after forty years of wandering), whose successors will probably hardly feel any connection to their Hungarian and Central-European roots. 
Rosen, Ilana. "Fragments of a Hungarian Past in the Literature of 1.5 and Second-Generation Austro-Hungarian Immigrants in Israel." Hungarian Cultural Studies. e-Journal of the American Hungarian Educators Association, Volume 7 (2014): http://ahea.pitt.edu DOI: 10.5195/ahea.2014.138

\section{Appendix: Hungarian-Israeli Writers and Writing*}

*In addition to the two Modern Hebrew Literature lexicons cited above, in preparing this Appendix I enjoyed the help and knowledge of Ben Gurion University graduate students Ruti Glick (Ph.D.) and Iris Flaum (Masters).

\section{Forefathers-Forerunners:}

Avigdor Hameiri (Foyerstein) (1890-1970, b. in Ujdávidháza, Carpatho-Rus'; emigrated to British-Mandate ruled Palestine/Israel in 1921); poet, prose writer, essayist. His most wellknown work is the story collection The Great Madness [Hashigaon Hagadol] (Tel Aviv: Dvir: 1929 [Eng. 1984, Hung. 2009]), on his experiences as a Hungarian soldier in World War I.

Mordechai Avi-Shaul (Mandel) (1898-1988, b. in Szólnok; emigrated to I/P in 1921 and settled in Jerusalem); poet, playwright and translator.

David Giladi (Klein) (1908-2009, b. in Szilágycheh, Erdély/Transylvania; emigrated to I/P in 1934); journalist, poet, translator, and editor.

\section{First Generation}

Hanna-Anna (Anikó) Szenes (1921-1944) was a poet and playwright born in Budapest to Katalin and writer Béla Szenes. She emigrated to I/P in 1939, studied at the Nahalal Women's Agricultural School and later lived in Kibbutz Sdot Yam. She was sent on a mission to Nazioccupied Hungary, where she was caught, tortured and executed. Szenes became the heroine of many literary works, plays and films. Her diaries and letters were published in several editions, including a comprehensive Hungarian one by Anna Szalai in 1991.

Ephraim Kishon (Ferenc Kishont-Hoffmann) (1924-2005, b. in Budapest; was incarcerated in a work camp in Hungary in World War II; emigrated to Israel in 1949); playwright, film director, essayist, and humoresque writer of international renown.

\section{Caricaturists/artists}

Shraga Weil (1918-2009), Shmuel Katz (1926-2010), Ze'ev (Yaakov Farkash) (1923-2002), Dosh (Kariel Gardosh née Goldberger) (1921-2000).

\subsection{Generation}

Moshe Ganan (János Kertész) (b. 1931 in Budapest; emigrated to I/P in 1947); poet, writer and translator.

Shulamit Lapid (b. 1934 in Tel Aviv), daughter of David Giladi. In addition to historical novels, a detective series, and children books, Lapid wrote Veulay lo hayu ['Maybe They Were Not'] (Jerusalem: Keter, 2011), on her parents as pioneers/immigrants and her childhood in Tel Aviv of the 1930s.

Itamar Yaoz-Keszt (b. 1934 in Szarvas, Hungary; was deported with his parents and sister to Bergen Belsen; emigrated to Israel in 1951); poet, prose writer, essayist, and translator. 
Rosen, Ilana. "Fragments of a Hungarian Past in the Literature of 1.5 and Second-Generation Austro-Hungarian Immigrants in Israel." Hungarian Cultural Studies. e-Journal of the American Hungarian Educators Association, Volume 7 (2014): http://ahea.pitt.edu DOI: 10.5195/ahea.2014.138

Yoel Hoffmann (b. Brasov, 1937, Romania; emigrated to Israel in 1938); writer of poem-like prose about the life of Austro-Hungarian immigrants in Israel of the 1950s-1970s, illuminated also by... Buddhist philosophy.

Yaakov Barzilai (a poet b. 1933 in Debrecen; was deported with his family to Bergen Belsen in World War II; emigrated to Israel in 1949, lived in Kibbutz Hatsor and later became founder of Kibbutz Dvir, both in the south of Israel).

Eli Netzer (Schnitzer) (a poet b. 1933 in Budapest, emigrated to Israel in 1949 and settled in Kibbutz Dalia in the north area). He is the founder of Maarechet Press, which specializes in documentary writing and published many works by people of Hungarian origin.

Asher Reich (a poet and translator b. 1937 in Jerusalem to an Ultra-Orthodox family, which he left as a youth).

Judith Rotem (b. 1942 in Budapest, her family escaped to Switzerland in the Kasztner Train and emigrated to I/P in 1946). She is a novelist, journalist and editor of Holocaust memoirs, of formerly observant-religious circles. She writes about women's life in Jewish Orthodoxy, Hungarian roots, and the Holocaust. Her distinctly "Hungarian" books are: Kria'a ['Mourning'] (Tel Aviv: Am Oved, 1996); Ahavti kolkakh ['I loved so Much'] (Tel Aviv: Yediot Achronot, 2000); Matay tavo elay ['When Will You Come to Me'] (Or Yehuda: Kineret, Zmora-Bitan, Dvir, 2012).

\section{Second Generation}

Agi Mishol (a poet b. 1946 in Szilágycheh/Chehu silvaniei, Romania, 1946; emigrated to Israel in 1950).

Miriam Neiger Fleischmann (a poet and artist b. 1948 in Komárom/Komarno, Czechoslovakia; emigrated to Israel in 1949).

Rivka Keren (Katalin Friedländer) (b. 1946 in Debrecen; emigrated to Israel in 1957); novelist and young-readers fiction writer.

Carmit Guy (b. 1949 in Kibbutz Givat Hayim and grew up in Kibbutz Yad Hannah [Szenes]; daughter of Holocaust survivors from Hungary); biographer and a radio and television broadcaster. She dedicated a book to Kibbutz Yad Hannah: Masa leyad hanna ['Journey to Yad Hannah'] (Tel Aviv: Am Oved, 1992).

Dorit Weissman (a poet b. 1950 in Kfar Sava to Holocaust survivors from Hungary). She wrote: Lirkod itach chardash ['Dancing Chardash with You'] (Ra'anana: Even Hoshen, 2005), for her late mother.

Hezi Leskli (1952-1994, a poet, choreographer and art critic b. in Israel to immigrants from Slovakia). 
Rosen, Ilana. "Fragments of a Hungarian Past in the Literature of 1.5 and Second-Generation Austro-Hungarian Immigrants in Israel." Hungarian Cultural Studies. e-Journal of the American Hungarian Educators Association, Volume 7 (2014): http://ahea.pitt.edu DOI: 10.5195/ahea.2014.138

Ofra Offer (a poet and novelist b. 1951 in Tel Aviv to Holocaust survivors from Hungary). She published A Letter to Mother: Memories of a Survivor of Incest (UK: Kindle Edition, 2011).

Shoshi Brainer (b. 1952 in Haifa to Holocaust survivors from Hungary). She wrote: Ariadna - Roman ['Ariadne: A Novel'] (Tel Aviv: Hakibutz Hameuchad, 1990), about the journey of a son of Holocaust survivors to Hungary and Czechoslovkia.

Suzanne Adam (b. 1954 in Szatmár/Satu Mare, Romania; emigrated to Israel in 1964). She wrote: Kvisa ['Laundry'] (Jerusalem: Keter, 2000) [Wäsche: Roman (trans. Barbara Linner) (München: Bertlesmann, 2003)]; Rekhush ganuv ['Stolen Property'] (Jerusalem: Keter, 2009); Ima shel Janis ['Janis' Mother'] (Jerusalem: Keter: 2004).

Yigal Schwartz (b. 1954 in Ramat Gan to survivors from Hungary); researcher and editor of Modern Hebrew literature; has recently published Makhela hungarit ['A Hungarian Chorus'], a multi-vocal literary memoir on his growing up in a family of heavily traumatized Holocaust survivors (reviewed in this volume of Hungarian Cultural Studies).

Robi Schoenberger (a poet and psychoanalyst b. 1960 in Temesvár/Timisoara, Romania; emigrated to Israel in the same year).

Yael Neeman (b. 1960 in Kibbutz Yehiam to Holocaust survivors from Hungary). She wrote: Hayinu he-atid ['We Were the Future'] (Tel Aviv: Ahuzat Bayit, 2011); "Optsiya," in The Option [Heb.: Ktovet esh, 'Fire Inscription'] (Jerusalem: Keter, 2013), 103-145.

Esti G. (Goldstein) Hayim (b. 1963 in Jaffa to Holocaust survivors from Budapest, grew up in Haifa). She wrote: Rakdanit Shchora belehakat yahid ['Black Dancer in a Solo Troupe'] (Tel Aviv: Hakibutz Hameuchad, 1997), a short story collection partly dealing with second generation to the Holocaust experiences of young people in Israel of the 1970s-1980s ("Ms. Adella Miller," 9-16; "71a Geula Street," 90-97); Hayenu hashniyim ['Our Other Lives'] (Tel Aviv: Hakibutz Hameuchad, 1999); Anshei Pinot ['Corner People'] (Or Yehuda: Kineret, Zmora-Bitan, Dvir, 2013).

\section{Third Generation}

Dávid Tarbay (b. 1977 in Budapest to writer Ede Tarbay and researcher Anna Szalai; emigrated to Israel in 1991); writer, translator, and musician.

A view on Israelis of Hungarian origin by non-Hungarian Israeli writers Hayim Sabato (b. 1952 in Cairo), From the Four Winds (Milford CT: Toby Press, 2010) [Heb. 2008].

Ora Ahimeir (b. 1941, in Jerusalem), Kalla ['Bride'] (Tel Aviv: Am Oved, 2012). 
Rosen, Ilana. "Fragments of a Hungarian Past in the Literature of 1.5 and Second-Generation Austro-Hungarian Immigrants in Israel." Hungarian Cultural Studies. e-Journal of the American Hungarian Educators Association, Volume 7 (2014): http://ahea.pitt.edu DOI: 10.5195/ahea.2014.138

\section{Works Cited}

Ahimeir, Ora. 2012. Kalla ['Bride']. Tel Aviv: Am Oved.

Bar-On, Dan. 2000. Bridging the Gap. Hamburg: Koerber.

Galron-Goldschläger, Joseph, ed. Ohio State University Modern Hebrew Literature Bio-Bibliographical Lexicon. http://library.osu.edu/projects/hebrew-lexicon.

Glick, Ruti. 2013. Asura be-erets hadasha - sipura shel ha-mehageret hannah senesh ['Captive in a New Land: The Story of Immigrant Hanna Szenes']. Haifa: Pardes.

Grossman, David. 2002. See under Love. Trans. Betsy Rosenberg. New York: Macmillan, Picador.

Hass, Aharon. 1996. In the Shadow of the Holocaust: The Second Generation. Cambridge: Cambridge University Press.

Hayim, Esti G. 2013. Anshei pinot ['Corner People']. Or Yehuda: Kineret, ZmoraBitan, Dvir.

Horváth, Rita. 2004. "A Changing Genre: Jewish Hungarian Family Novels after the Holocaust." Yad Vashem Studies 32: 209-226.

Milner, Iris. 2009. Hanarativim shel hashoah ['Holocaust Literature']. Tel Aviv: Hakibutz Haemuchad.

Neeman, Yael. 2011. Hayinu he-atid ['We Were the Future']. Tel Aviv: Ahuzat Bayit.

Rosen, Ilana. 2003. Sister in Sorrow: Life Histories of Female Holocaust Survivors from Hungary. Detroit, MI: Wayne State University Press.

- 2004. Hungarian-Jewish Women Survivors Remember the Holocaust: An Anthology of Life Histories. Lanham, MD: University Press of America, Rowman and Littlefield.

- 2011. Soul of Saul: The Life, Narrative, and Proverbs of a HungarianIsraeli Grandfather, Proverbium Supplementary Series vol. 31. Burlington, VT: Vermont University.

. 2012. "Soldiers or Slaves? Narratives of Survivors of the Hungarian Army's 'Labor Service' in World War II and the Holocaust." Dapim: Studies on the Shoah 26: 95-123.

Rosenhouse, Judith. 2012. "Israeli Hebrew and Hungarian Interaction." Rhythm, Melody and Harmony in Speech: Studies in Honour of Wiktor Jassen, Speech and Language Technology. Eds. Dafydd Gibbon, Daniel Hirst and Nick Campbell, 1415.4: 211-224.

Rotem, Judith. 2000. Ahavti kolkakh ['I Loved So Much']. Tel Aviv: Yediot Achronot. 2012. Matay tavo elay ['When Will You Come to Me']. Or Yehuda: Kineret, Zmora-Bitan, Dvir.

Rubin Suleiman, Susan. 2002. "The 1.5 generation." American Imago 59/3: 277-295.

Sabato, Hayim. 2010. From the Four Winds. Milford CT: Toby Press.

Schwartz, Yigal. 2014. Askenazim - hamerkaz neged hamizrah ['Ashkenazim: Center vs. East']. Or Yehuda and Ramat Gan: Dvir and Bar Ilan University Press.

Schwartz, Yigal. 2014. Makhela hungarit ['A Hungarian Chorus']. Or-Yehuda: Kinneret, Zmora-Bitan, Dvir. 
Rosen, Ilana. "Fragments of a Hungarian Past in the Literature of 1.5 and Second-Generation Austro-Hungarian Immigrants in Israel." Hungarian Cultural Studies. e-Journal of the American Hungarian Educators Association, Volume 7 (2014): http://ahea.pitt.edu DOI: 10.5195/ahea.2014.138

Shaked, Gershon. 2000. Modern Hebrew Fiction. Bloomington: Indiana University Press.

Shenhav, Yehuda. 2006. The Arab-Jews: A Postcolonial Reading of Nationalism, Religion, and Ethnicity. Redwood City, CA: Stanford University Press.

Stavi, Zissi and Yigal Schwartz, eds. Lexicon heksherim lesofrim yisraelim ['The Heksherim Lexicon of Israeli Authors']. Beer Sheva and Or Yehuda: Heksherim Institute at Ben Gurion University of the Negev and Kineret, Zmora-Bitan, Dvir Publishers, 2014.

Swedenberg, Ted. 2003. Memories of Revolt: The 1936-1939 Rebellion and the Palestinian National Past. Fayetteville, ARK: University of Arkansas Press.

Vardi, Dina. 1992. Memorial Candles: Children of the Holocaust. London: Tavistock, Routledge.

Zaicz, Gábor. 2006. Etimológiai szótár - Magyar szavak és toldalékok eredete. Budapest: Tinta Könyvkiadó. 